\title{
Pemanfaatan perjanjian perdagangan internasional melalui pemberdayaan UMKM oleh FTA Center Jakarta periode 2018- 2019
}

\section{Surjadi Basuki ${ }^{\star}$}

Fakultas Ekonomi dan Bisnis, Universitas Indonesia, Indonesia

*surjadi.a@ui.ac.id

\begin{abstract}
Indonesia is significantly intensifying the international-trade agreement with several strategic trade partners. Some said that the agreement would lead to the increasing flow of imported goods to Indonesia. Free Trade Agreement (FTA) Center Jakarta indeed aimed at empowering Indonesian small and medium enterprises (SMEs) to enjoy the benefits of more open export opportunities. Through coaching clinic and personal consultation method, the SMEs acquire knowledge on available export opportunities and training to improve the skills that suitable to their needs. Within a year of the empowerment program, around 100 SMEs have been reaching positive achievements that increase their confidences in penetrating export market or expanding their export activities.
\end{abstract}

\begin{abstract}
Abstrak Indonesia semakin banyak membuat perjanjian perdagangan internasional dengan sejumlah negara mitra dagang strategis. Beberapa kalangan berpandangan bahwa perjanjian-perjanjian tersebut akan meningkatkan serbuan barang impor ke Indonesia. Free Trade Agreement (FTA) Center Jakarta justru ingin memberdayakan UMKM Indonesia agar dapat memanfaatkan peluang ekspor yang semakin terbuka. Melalui metode coaching clinic dan konsultasi perorangan, para pelaku UMKM memeroleh pengetahuan tentang peluangpeluang ekspor yang tersedia serta pelatihan tentang peningkatan keterampilan yang disesuaikan dengan kebutuhan mereka. Selama satu tahun program pemberdayaan, sekitar 100 pelaku UMKM telah meraih pencapaian-pencapaian positif yang dapat meningkatkan optimisme mereka dalam upaya menembus pasar ekspor atau mengembangkan kegiatan ekspor mereka.
\end{abstract}

Keywords: empowerment; SMEs; export opportunity

\section{OPEN ACCESS}

Citation: Basuki, S. (2020). Pemanfaatan perjanjian perdagangan internasional melalui pemberdayaan UMKM oleh FTA Center Jakarta periode 2018-2019. Riau Journal of Empowerment, 3(3), 149-160. https://doi.org/10.31258/raje.3.3.149-160

Paper type: Community service

Received: 2020-07-28 Revised: 2020-08-25 Accepted: 2020-08-26

Language: Bahasa Indonesia (id)

ISSN 2623-1549 (online), 2654-4520 (print)

(C) 2020 Surjadi Basuki. Author(s) retain the copyright of article published in this journal, with first publication rights granted to Riau Journal of Empowerment. The article is licenced under Creative Commons Attribution 4.0 Internationa License. This license permits unrestricted use, distribution, and reproduction in any medium, provided the original author and source are credited. 


\section{PENDAHULUAN}

Sejak 1992 Indonesia telah terlibat dalam ASEAN Free Trade Area (AFTA) yaitu suatu kawasan perdagangan bebas yang dibentuk melalui perjanjian perdagangan antar negaranegara ASEAN dengan tujuan mempermudah perdagangan antar sesama negara ASEAN melalui penurutan tarif bea masuk atas barang-barang impor. Memasuki milenium ketiga, sesuai dengan panggilan zaman dimana perdagangan internasional semakin dipermudah dengan internet dan sejumlah kemajuan teknologi lainnya, Indonesia meningkatkan pembuatan perjanjian dengan negara-negara mitra dagang strategis baik melalui jalur ASEAN maupun secara bilateral. Pada 2004, ASEAN dan Tiongkok membentuk ASEAN-China Free Trade Area (AC-FTA) yang kemudian pada 2006 disusul dengan pembentukan ASEAN-Korea FTA (AK-FTA). Di jalur bilateral, pada 2007 Indonesia dan Jepang membentuk IndonesiaJapan Economic Partnership Agreement (IJEPA) yang selain memperlancar kegiatan perdagangan antar kedua negara juga mengatur kemudahan-kemudahan untuk melakukan investasi serta kegiatan ekonomi lainnya. Selanjutnya pembentukan perjanjian-perjanjian perdagangan internasional terus meningkat, dengan Direktorat Jenderal Perjanjian Perdagangan Internasional (Ditjen PPI) Kementerian Perdagangan Republik Indonesia (Kemendag RI) sebagai ujung tombak dalam proses perundingan-perundingan yang dilakukan.

Di tengah optimisme bahwa berbagai perjanjian perdagangan internasional tersebut akan dapat membawa dampak positif bagi neraca perdagangan serta perekonomian Indonesia, bermunculan suara-suara kritis yang berkeberatan terhadap langkah pemerintah mengintensifkan perundingan-perundingan perjanjian perdagangan internasional. Sejumlah kalangan akademisi, politisi serta berbagai kelompok masyarakat menyuarakan kekhawatiran bahwa perjanjian-perjanjian perdagangan internasional lebih banyak menimbulkan dampak negatif ketimbang dampak positifnya. Sebagai contoh, salah satu kolom opini di media massa menampilkan judul "FTA dan CEPA, Masih Perlukah?" (Hasan, 2017).

Selaras dengan perkembangan perjanjian perdagangan internasional yang telah ditandatangani atau sedang dirintis oleh Indonesia, sekaligus untuk menjawab kritik-kritik yang ada, pada 31 Mei 2018 Ditjen PPI Kemendag RI meresmikan pembentukan Free Trade Agreement (FTA) Center di Jakarta, Bandung, Medan, Surabaya dan Makassar. FTA Center mendorong para pelaku usaha Indonesia untuk meningkatkan ekspor dengan memanfaatkan berbagai perjanjian perdagangan internasional yang telah dibuat oleh Indonesia. Pada masa bakti pertama FTA Center Jakarta, yaitu 2018-2019, penulis sebagai seorang akademisi di ilmu ekonomi terpilih menjadi Tenaga Ahli untuk bidang implementasi hasil perjanjian perdagangan internasional. Penulis bertanggungjawab untuk menjelaskan konsekuensi dari perjanjian-perjanjian perdagangan internasional yang telah dibuat Indonesia bersama para mitra dagang. Tentu saja konsekuensi semakin berkurangnya tarif bea masuk di negara tujuan ekspor harus dapat kita manfaatkan secara optimal. Penulis bertugas dalam satu tim bersama dua orang rekan Tenaga Ahli yang masing-masing memiliki tugas di bidang akses pembiayaan dan prosedur ekspor dan bidang strategi promosi dan pemasaran serta dua orang tenaga pendukung yang membantu kegiatan administrasi dan logistik sehari-hari.

Tugas utama yang dibebankan kepada kami sebagai Tenaga Ahli di FTA Center Jakarta adalah memberdayakan pelaku usaha, khususnya Usaha Mikro, Kecil dan Menengah (UMKM) untuk dapat melakukan ekspor atau meningkatkan ekspor ke negara-negara yang memiliki perjanjian perdagangan internasional dengan Indonesia. Pada 2018 pelaku UMKM di Indonesia meliputi sekitar 99\% entitas bisnis di Indonesia dengan kontribusi sekitar 61\% 
dari PDB harga berlaku. Selama ini UMKM, yang pada 2018 menampung sekitar 97\% pekerja Indonesia, terbukti memiliki kemampuan bertahan yang sangat baik dalam menghadapi berbagai gejolak perekonomian, termasuk krisis ekonomi Indonesia 1997/98 serta krisis ekonomi dunia 2008/2009. Namun kontribusi UMKM dalam ekspor Indonesia pada 2018 baru sekitar 15\% (Kementerian Koperasi dan Usaha Kecil dan Menengah, 2018). Hal ini mengindikasikan bahwa ekspor Indonesia masih didominasi oleh usaha-usaha besar.

Itulah sebabnya diperlukan intervensi khusus dari pemerintah berupa pemberdayaan pelaku UMKM agar semakin banyak yang bisa melakukan ekspor. FTA Center dipilih melakukan pemberdayaan tersebut dengan secara khusus berfokus pada negara-negara mitra dagang yang sudah terikat perjanjian dengan Indonesia untuk saling mempermudah kegiatan ekspor. Sebelum menjalankan tugas yang berat ini, para Tenaga Ahli FTA Center mendapat pembekalan dari para narasumber yang berkompeten dalam bidang-bidang yang berhubungan dengan kegiatan ekspor.

Kinerja ekspor para pelaku UMKM yang relatif rendah, tak lepas dari banyaknya keterbatasan yang mereka miliki dalam mengakses informasi tentang kegiatan ekspor secara umum. Apalagi kegiatan ekspor dalam konteks FTA atau bentuk perjanjian perdagangan internasional lainnya. FTA Center Jakarta menghadapi pertanyaan besar bagaimana menghadirkan program-program pemberdayaan agar para pelaku UMKM dapat memanfaatkan perjanjian-perjanjian perdagangan internasional yang telah diikuti Indonesia. Kendala-kendala yang dihadapi oleh para pelaku UMKM harus dapat ditemukenali untuk kemudian diatasi bersama-sama. Upaya-upaya yang dilakukan oleh FTA Center Jakarta selama periode 2018-2019 akan diuraikan lebih lanjut dalam tulisan ini.

\section{METODE PENERAPAN}

Metode pemberdayaan pelaku UMKM yang dipilih oleh FTA Center Jakarta adalah berupa coaching clinic dan konsultasi perorangan. Metode coaching clinic dipilih karena tingkat efektivitasnya yang cukup baik bagi kegiatan pemberdayaan masyarakat. Studi Hudlicka (2013) menunjukkan bahwa coaching clinic bersifat efektif dalam mengubah perilaku seseorang. Kekhasan dari metode ini adalah peserta program pemberdayaan dapat dibimbing oleh para coach yang siap memberi contoh bagaimana meningkatkan kualitas produk ataupun menembus pasar ekspor. Jadi para pelaku UMKM bukan sekedar mendengarkan alunan teori berbasis buku teks yang sulit dicerna oleh hati dan pikiran. Tentu saja setiap coach yang tampil harus memiliki kemampuan yang mumpuni untuk memberdayakan pelaku UMKM di era disruptif ini (Sani \& HSM, 2020).

Sementara itu, konsultasi perorangan dilakukan karena juga telah terbukti efektivitasnya dalam program pemberdayaan. Studi menunjukkan bahwa konsultasi perorangan cocok untuk diterapkan dalam kegiatan pemberdayaan (Aitken et al., 2016). Konsultasi adalah salah satu fungsi yang harus dijalankan oleh FTA Center Jakarta, selain edukasi dan advokasi. Dengan demikian fungsi konsultasi yang dilakukan adalah bagian dari paket lengkap program pemberdayaan yang juga disertai edukasi dan advokasi. Penelitian telah membuktikan bahwa proses konsultasi yang berjalan dengan efektif dapat membantu upaya peningkatan keterampilan seseorang (Lochner \& Gijselaers, 2011).

Baik coaching clinic maupun konsultasi perorangan dijalankan sesuai prinsip bottom-up yang sejak lama telah dinilai sebagai pendekatan yang tepat bagi kegiatan pemberdayaan masyarakat (Riga, 2020). Pendekatan ini menempatkan aspirasi para pelaku UMKM sebagai 
acuan awal proses pemberdayaan. Sebagai contoh untuk memberikan pelatihan dalam konteks ekspor, terlebih dahulu pelaku UMKM diberi kesempatan untuk menyampaikan pengetahuan ataupun keterampilan apa saja yang dibutuhkan. Jadi para coach dalam kegiatan pemberdayaan ini tidak berangkat dengan serangkaian jurus-jurus yang siap diturunkan kepada semua pelaku UMKM tanpa memerhatikan kebutuhan riil mereka.

Setiap peserta kegiatan pemberdayaan baik melalui coaching clinic maupun konsultasi perorangan memiliki catatan pencapaian yang dibuat oleh para tenaga ahli FTA Center Jakarta, sesuai dengan permasalahan yang mereka hadapi dalam melakukan ekspor atau mempersiapkan ekspor. Setiap bulan catatan pencapaian ini dilaporkan kepada Kementerian Perdagangan RI. Dengan mengacu ke catatan pencapaian ini dapat diamati perkembangan jumlah UMKM yang mengikuti kegiatan pemberdayaan serta kinerja tiap-tiap pelaku usaha tersebut.

\section{HASIL DAN KETERCAPAIAN SASARAN}

Proses pemberdayaan pelaku UMKM oleh FTA Center Jakarta dimulai dari penyusunan rencana kegiatan oleh para Tenaga Ahli. Mengingat ketiga orang Tenaga Ahli tidak berasal dari kalangan birokrat, maka proses penyusunan rencana kegiatan dapat berjalan dalam suasana demokratis yang penuh dengan kesetaraan. Tidak ada upaya-upaya "menunggu arahan" dan penyusunan aneka prosedur khas birokrasi (Kartiwa, 2020). Rencana kegiatan yang dibuat benar-benar berorientasi pada pencapaian tujuan FTA Center secara efektif dan efisien. Untuk bisa berkonsultasi dengan para Tenaga Ahli, pelaku UMKM bisa menggunakan berbagai aplikasi media sosial atau berkunjung langsung ke kantor kami. Bahkan para Tenaga Ahli siap untuk mengunjungi para pelaku UMKM atau pihak-pihak yang dapat bekerjasama dalam kegiatan pemberdayaan masyarakat seperti Pemerintah Daerah, kalangan perbankan, asosiasi pelaku usaha, universitas dan lain-lain.

FTA Center Jakarta memilih metode utama pemberdayaan pelaku UMKM melalui kegiatan coaching clinic yang disertai dengan kemitraan dengan Pemerintah Daerah serta kegiatan konsultasi perorangan yang berjalan dengan seramah mungkin bagi para pelaku usaha. Dua orang rekan Tenaga Ahli memiliki pengalaman berkecimpung di perusahaanperusahaan swasta yang melakukan ekspor sehingga sangat memahami psikologi yang dimiliki oleh para pelaku UMKM jika diajak untuk mengikuti program-program pemberdayaan. Dalam menjalankan kegiatan pemberdayaan, FTA Center Jakarta mengupayakan agar dapat tercipta diskusi interaktif dengan para pelaku usaha dan menghindari pendekatan top-down yang sering terjadi saat para pelaku usaha mengikuti program pemberdayaan yang diselenggarakan oleh Pemerintah.

\section{Coaching clinic}

Selama satu tahun periode bakti kami di FTA Center Jakarta, telah dilangsungkan 3 kali kegiatan coaching clinic yaitu di Jakarta, Kota Bogor dan Kota Tangerang Selatan. Jumlah kegiatan tersebut tidak lepas ada kendala sumber daya yang ada, terutama anggaran yang dialokasikan oleh Ditjen PPI Kemendag RI. Seluruh pelayanan FTA Center Jakarta kepada para pelaku UMKM adalah bebas biaya. Coaching clinic di Jakarta sebagai kegiatan pertama adalah saat dimana kami masih mencari format pemberdayaan yang ideal. Selain ada presentasi dan konsultasi dari para Tenaga Ahli (yang berperan sebagai coach), dihadirkan pula eksportir barang kerajinan dan juga eksportir kopi luwak dalam sesi berbagi pengalaman 
kepada sesama UMKM. Kami juga menghadirkan pihak perbankan dan penyedia dana yang sehari-harinya sudah terbiasa bekerja sama dalam pendanaan ekspor, yaitu Bank Mandiri dan Koperasi Simpan Pinjam Asy-Syirkah. Adapun para pesertanya berjumlah sekitar 20 orang yang sebelumnya sudah pernah berkonsultasi dengan kami dan menurut penilaian kami memiliki potensi untuk menjadi eksportir. Pada coaching clinic di Kota Bogor dan Kota Tangerang Selatan, format pemberdayaan yang kami berikan semakin menemukan bentuk yang ideal, terutama dalam seleksi peserta. Kami bermitra dengan Dinas Perindustrian dan Perdagangan setempat yang sehari-hari sudah berinteraksi dengan pelaku UMKM sehingga bisa mengetahui secara tepat siapa saja yang berpotensi untuk diberdayakan menjadi eksportir.

Kegiatan coaching clinic dimulai dengan transfer pengetahuan melalui presentasi ketiga Tenaga Ahli FTA Center Jakarta tentang pengertian umum FTA seperti: negara-negara mana saja yang menjadi mitra FTA, bagaimana memanfaatkan fasilitas tarif bea masuk hingga $0 \%$ di negara mitra FTA, berbagai formulir yang harus digunakan untuk bisa mendapatkan fasilitas tarif bea masuk di negara mitra FTA serta Surat Keterangan Asal (SKA) atau Certificate of Origin (COO) sebagai salah satu persyaratan untuk mendapatkan fasilitas tarif bea masuk tersebut. Selain itu juga diberikan penjelasan umum tentang bagaimana pembiayaan ekspor serta strategi pemasaran produk ekspor. Selain oleh Tenaga Ahli FTA Center, transfer pengetahuan juga diberikan oleh pembicara tamu sesama pelaku UMKM yang sudah berhasil melakukan ekspor. Kami biasa menyebut kegiatan ini sebagai "sesi berbagi pengalaman" (sharing session). Pada umumnya para pelaku UMKM termotivasi oleh sesi ini sehingga banyak mengajukan pertanyaan bahkan tak segan berupa curahan hati ("curhat") tentang kendala-kendali yang mereka hadapi.

Setelah kegiatan transfer pengetahuan, dilakukan coaching oleh masing-masing Tenaga Ahli. Para peserta akan dibagi ke dalam meja-meja khusus dimana di setiap meja terdapat coach yaitu ketiga Tenaga Ahli serta para coach tamu yang siap memberikan berbagai pelatihan kepada para peserta. Isu yang dibahas disesuaikan dengan kebutuhan para peserta. Biasanya para pelaku UMKM sudah menyiapkan pertanyaan atau isu yang hendak dibahas. Mulai dari penentuan harga yang tepat untuk produk yang dimiliki, alternatif mencari pendanaan untuk pembiayaan ekspor hingga strategi mencari calon pembeli di luar negeri. Masing-masing dibahas sesuai produk khas yang dihasilkan oleh masing-masing pelaku UMKM. Kami selalu menyediakan meja khusus untuk menampilkan produk-produk tersebut (lihat Gambar 1 dan Gambar 2) sebagai sarana para peserta untuk saling mengenal produk mereka dan berdiskusi.

Sesi coaching ini biasanya lebih fleksibel. Dimana para peserta dapat berpindah-pindah meja diskusi sepanjang waktu masih tersedia. Susunan meja bagi para peserta coaching clinic dapat dilihat di Gambar 2. Seluruh rangkaian coaching clinic berlangsung selama satu hari, dari sekitar jam 9 pagi hingga jam 5 sore. Biasanya para pelaku UMKM merasa waktu yang tersedia tidak mencukupi. Itulah sebabnya FTA Center Jakarta telah menyiapkan konsultasi lanjutan secara perorangan, bagi mereka yang membutuhkan. Seketika setelah kegiatan coaching clinic selesai, tenaga pendukung FTA Center Jakarta akan memasukkan atau memutakhirkan basis data para pelaku UMKM sebagai peserta program pemberdayaan yang kami lakukan. 


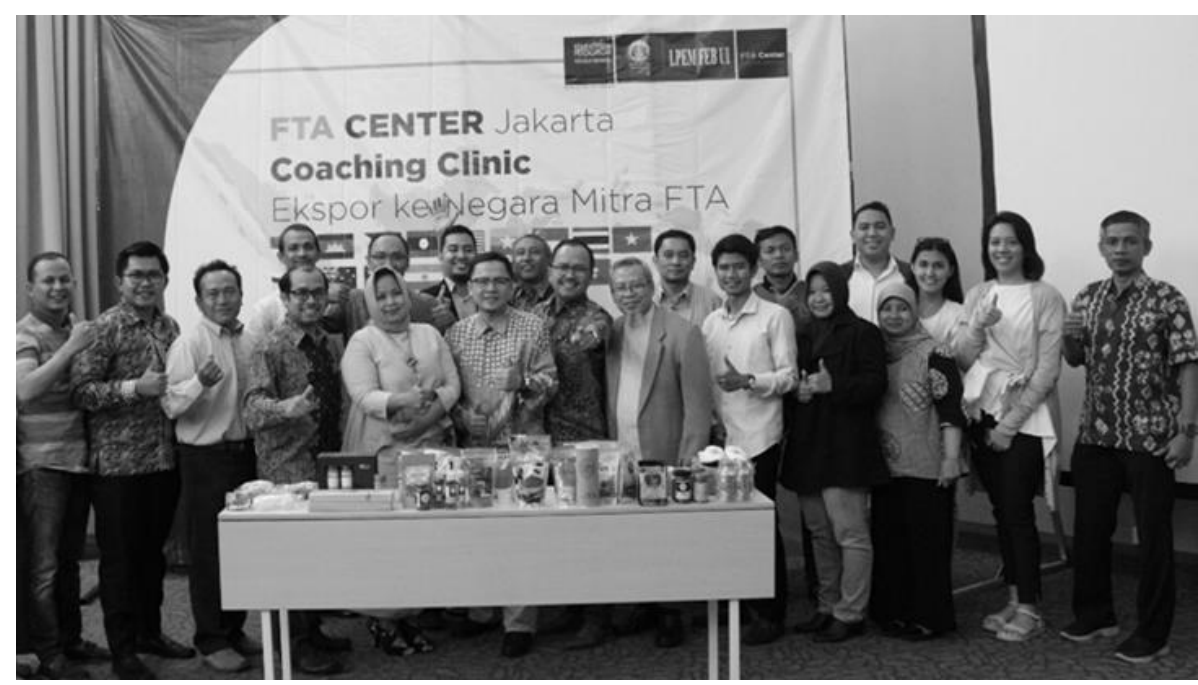

Gambar 1. Kegiatan coaching clinic di Jakarta (foto: FTA Center Jakarta)

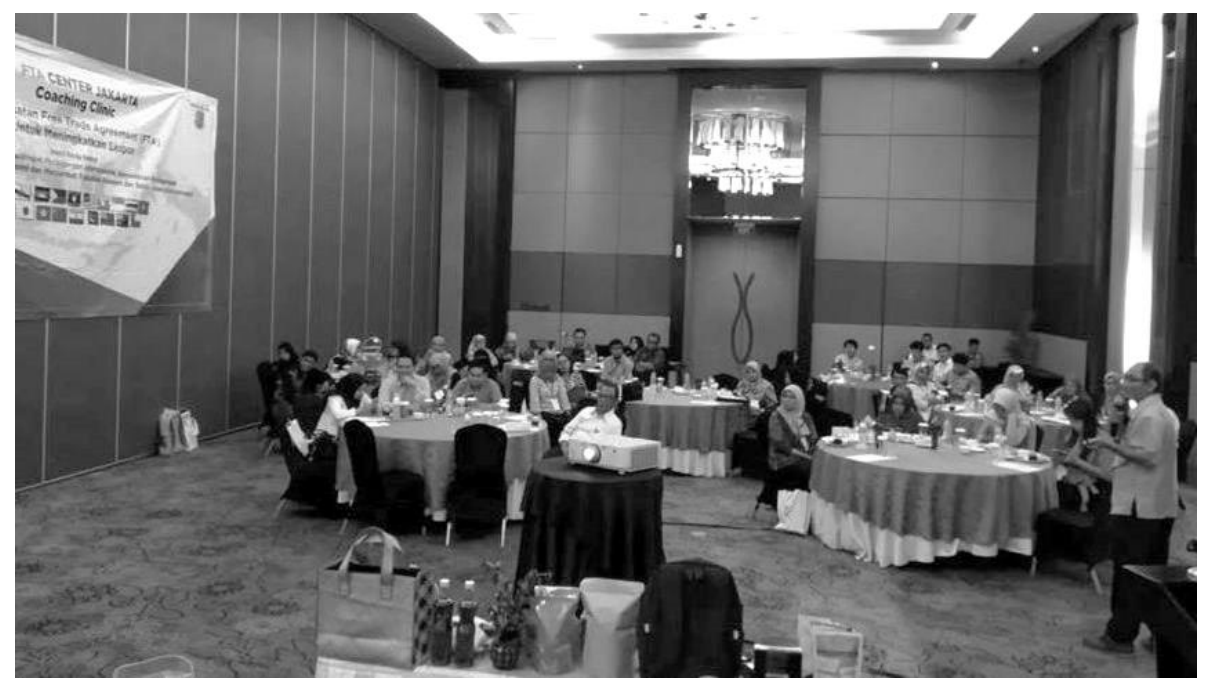

Gambar 2. Kegiatan coaching clinic di Tangerang Selatan (foto: FTA Center Jakarta)

\section{Konsultasi perorangan}

Sebagai pelengkap kegiatan coaching clinic, kami melayani konsultasi perorangan. Pelaku UMKM yang ingin berkonsultasi secara langsung dengan para TA FTA Center Jakarta dapat datang langsung ke kantor kami di Kementerian Perdagangan Jl. M. I. Ridwan Rais Jakarta Pusat atau bisa juga melalui jalur komunikasi lain seperti video call atau email serta media sosial (Facebook, WhatsApp, dan Instagram). Mengingat keterbatasan waktu yang ada serta demi kenyamanan bersama, biasanya kegiatan konsultasi perorangan ini dilakukan setelah melalui proses penjadwalan terlebih dahulu. Kegiatan konsultasi sedapat mungkin melibatkan ketiga tenaga ahli FTA Center Jakarta dan bisa dilakukan di ruang rapat (Gambar 3, atas) maupun di ruang tamu (Gambar 3, bawah) tergantung pada kebutuhan dan jumlah tamu yang hadir. 

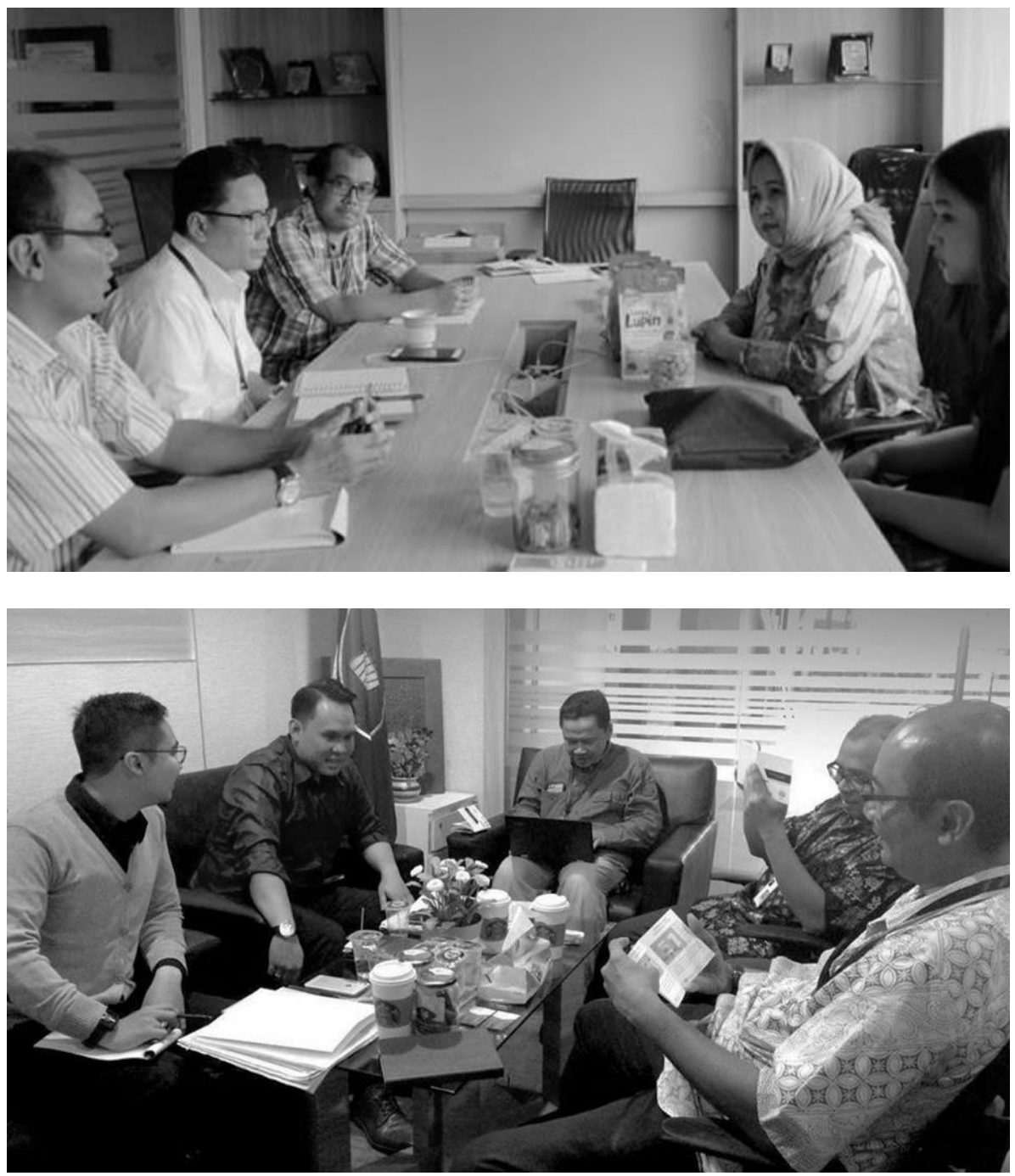

Gambar 3. Kegiatan konsultasi di kantor FTA Center Jakarta (foto: FTA Center Jakarta)

Beberapa keunggulan yang diperoleh dari konsultasi perorangan dalam program pemberdayaan ini adalah (1) menghadirkan suasana yang kondusif yaitu bisa berkomunikasi secara tatap muka secara intensif serta meningkatkan rasa saling mengerti. Forum coaching clinic atau pertemuan dengan banyak peserta terkadang menimbulkan rasa sungkan bagi para peserta, terutama pelaku usaha kecil, untuk mengungkapkan permasalahan yang dihadapi. (2) Dapat membahas secara rinci permasalahan yang dihadapi oleh pelaku usaha, dari aspek makro misalnya tentang pengetahuan terhadap FTA hingga aspek mikro seperti bagaimana merancang kemasan produk yang sesuai dengan standar di negara tujuan ekspor. Hal-hal yang tidak bisa dibahas dalam coaching clinic dapat didiskusikan melalui konsultasi perorangan. (3) Memungkinkan adanya mitigasi secara khas, misalnya memfasilitasi pertemuan dengan calon pembeli di luar negeri, membuka komunikasi dengan asosiasi pelaku usaha, memperkenalkan kepada pihak perbankan yang akan membantu pembiayaan, memeroleh masukan dari kalangan universitas dan lain-lain.

Para calon eksportir ini pada umumnya belum mengetahui kode HS untuk barang-barang yang mereka hasilkan. Oleh karena itu biasanya langkah pertama yang dilakukan dalam konsultasi adalah mengidentifikasi kode HS untuk barang-barang yang diproduksi. Selanjutnya diidentifikasi tarif bea masuk yang akan dikenakan di negara-negara mitra FTA terdekat yaitu ASEAN. Secara umum barang-barang yang dihasilkan oleh para calon eksportir 
menghadapi tarif bea masuk 0\% di negara-negara ASEAN. Dengan demikian ASEAN dapat menjadi prioritas sasaran ekspor bagi para calon eksportir tersebut.

Tak jarang pula kegiatan konsultasi perorangan ini diikuti oleh pelaku UMKM yang sudah pernah melakukan ekspor namun ingin memperluas pasar atau menghadapi suatu kendala saat bertransaksi. FTA Center Jakarta akan mendokumentasikan semua permasalahan yang ada dan melakukan mitigasi dengan semaksimal mungkin. Salah satu temuan menarik dari para eksportir ini adalah bahwa pada umumnya mereka melakukan ekspor secara "under name". Artinya mereka menyerahkan proses pengiriman barang ke luar negeri itu melalui jasa perusahaan perdagangan, atau yang biasa dikenal sebagai "trader". Alasan para pelaku UMKM adalah proses administrasi ekspor sangat rumit dan memakan waktu. Proses pengiriman barang ekspor tersebut kemudian dilakukan oleh "trader" yang dalam administrasi kepabeanan tercatat sebagai eksportir. Sementara peran para pelaku UMKM yang memroduksi barang tersebut sama sekali tidak tercatat, sehingga mereka tidak memiliki rekam jejak sebagai eksportir. Padahal rekam jejak serta kualitas produk ini sangat penting bagi kredibilitas mereka dalam melakukan negosiasi dengan calon pembeli di masa depan (Murtiasri et al., 2015). Disinilah pentingnya pemberdayaan oleh FTA Center Jakarta. Kami terus meyakinkan para eksportir UMKM akan pentingnya mengekspor atas nama sendiri, sambil membantu mereka mengatasi kendala-kendala yang mereka hadapi.

\section{Basis data UMKM}

Setiap pelaku usaha UMKM yang telah mengikuti coaching clinic atau berkonsultasi dengan FTA Center Jakarta akan dimasukkan ke dalam basis data kami. Para pelaku usaha yang kami berdayakan terbagi menjadi dua kelompok besar yaitu mereka yang sudah pernah melakukan ekspor dan mereka yang belum pernah melakukan ekspor. Dalam basis data tersebut akan dicatat permasalahan yang dihadapi oleh masing-masing pelaku usaha berserta perkembangan mitigasi yang telah dilakukan oleh para Tenaga Ahli. Tabel 1 menyajikan contoh basis data yang disusun.

Tabel 1. Contoh format basis data yang dihimpun oleh FTA Center Jakarta

\begin{tabular}{|c|c|c|c|}
\hline $\begin{array}{c}\text { Nama } \\
\text { UMKM }\end{array}$ & Permasalahan & Mitigasi & Tindak lanjut \\
\hline \multicolumn{4}{|c|}{ Kelompok A: Eksportir } \\
\hline TC, Bogor & $\begin{array}{l}\text { Pelaku usaha memperoleh } \\
\text { permintaan dari luar negeri } \\
\text { untuk produk bahan tekstil } \\
\text { yang tidak tersedia } \\
\text { Indonesia sehingga harus } \\
\text { diimpor dari China. Saat } \\
\text { akan mengekspor terbentur } \\
\text { dengan regulasi yang tidak } \\
\text { memungkinkan adanya } \\
\text { penerbitan Surat } \\
\text { Keterangan Asal (SKA) } \\
\text { dari Indonesia. }\end{array}$ & $\begin{array}{l}\text { Tenaga Ahli } \\
\text { berkonsultasi dengan } \\
\text { pejabat Direktorat } \\
\text { Fasilitasi Ekspor-Impor } \\
\text { Ditjen Perdagangan Luar } \\
\text { Negeri Kemendag RI, } \\
\text { dan alternatif: } \\
\text { 1. Dilakukan } \\
\text { pengolahan lebih } \\
\text { lanjut (misalnya } \\
\text { pemberian warna) } \\
\text { sehingga memenuhi } \\
\text { ketentuan SKA } \\
\text { Indonesia } \\
\text { 2. Melakukan ekspor } \\
\text { dengan skema "third- } \\
\text { party invoicing" yaitu } \\
\text { pelaku usaha } \\
\text { melakukan ekspor }\end{array}$ & $\begin{array}{l}\text { Melakukan pemantauan } \\
\text { atas pelaksanaan } \\
\text { alternatif yang telah } \\
\text { diberikan }\end{array}$ \\
\hline
\end{tabular}




\begin{tabular}{|c|c|c|c|}
\hline \multirow[t]{2}{*}{$\begin{array}{c}\text { Nama } \\
\text { UMKM }\end{array}$} & \multirow[t]{2}{*}{ Permasalahan } & \multirow{2}{*}{\begin{tabular}{l}
\multicolumn{1}{c}{ Mitigasi } \\
dari China dengan \\
bill of lading atas \\
nama pelaku usaha \\
dan penagihannya \\
ditujukan ke pelaku \\
usaha di Indonesia.
\end{tabular}} & \multirow[t]{2}{*}{ Tindak lanjut } \\
\hline & & & \\
\hline \multicolumn{4}{|c|}{ Kelompok B: Calon Eksportir } \\
\hline DC, Bogor & $\begin{array}{l}\text { 1. Belum mengetahui } \\
\text { kode HS untuk } \\
\text { produknya } \\
\text { 2. Belum mengetahui } \\
\text { negara yang menjadi } \\
\text { pasar potensial } \\
\text { produknya }\end{array}$ & $\begin{array}{l}\text { 1. Perkiraan kode HS } \\
\text { untuk produknya } \\
\text { adalah: 1518.00.19 } \\
\text { (minyak nabati lain- } \\
\text { lain), 1602.50.00 } \\
\text { (olahan daging } \\
\text { lembu), kelompok } \\
21.03 \text { (campuran } \\
\text { bumbu dan campuran } \\
\text { bahan penyedap). } \\
\text { 2. Membantu } \\
\text { mengidentifikasi } \\
\text { pasar potensial } \\
\text { melalui situs internet } \\
\text { internasional yang } \\
\text { terpercaya. }\end{array}$ & $\begin{array}{l}\text { 1. Memantau persiapan } \\
\text { menuju kegiatan } \\
\text { ekspor } \\
\text { 2. Memperkenalkan } \\
\text { produk-produknya } \\
\text { melalui berbagai } \\
\text { sarana yang dimiliki } \\
\text { FTA Center Jakarta }\end{array}$ \\
\hline
\end{tabular}

\section{Fasilitas bagi UMKM yang diberdayakan}

FTA Center Jakarta memfasilitasi pelaku UMKM yang telah diberdayakan dengan menerbitkan katalog produk (tercetak dan versi dalam jaringan) yang kemudian kami sebarluaskan kepada masyarakat. Contoh katalog versi cetak dapat dilihat pada Gambar 4. Katalog ini juga merupakan bentuk indikator pencapaian bagi para pelaku UMKM. Produkproduk yang ditampilkan dalam katalog haruslah dalam kemasan yang kami nilai sudah cukup layak untuk ditampilkan kepada publik. Jika produknya adalah makanan dan minuman maka harus sudah memiliki informasi tentang tanggal kedaluwarsa, kandungan gizi, berat bersih, dan lain-lain. Bagi produk makanan dan minuman yang kemasannya belum memenuhi syarat, maka terlebih dahulu akan memeroleh bimbingan dari para Tenaga Ahli FTA Center Jakarta.
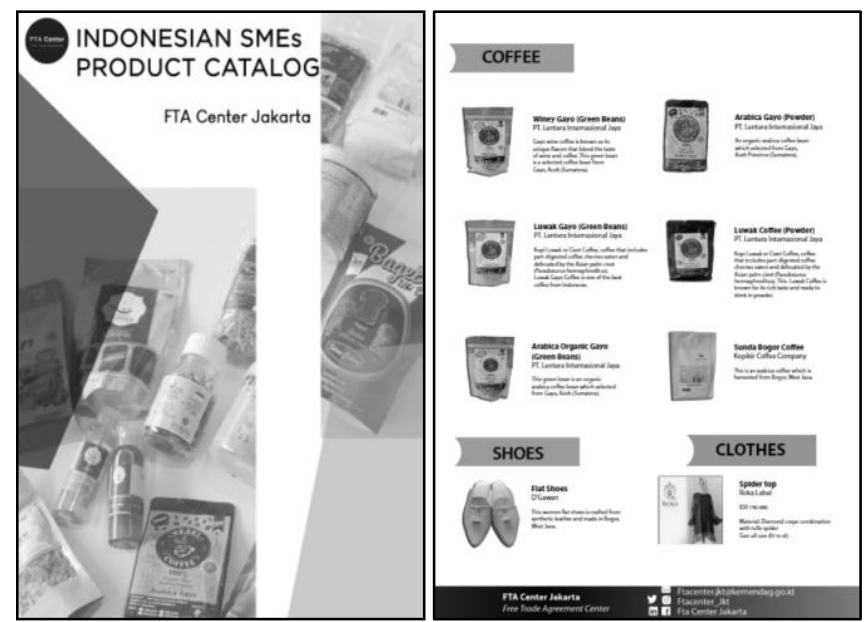

Gambar 4. Katalog produk UMKM yang telah mengikuti pemberdayaan oleh FTA Center Jakarta (foto: FTA Center Jakarta) 
Produk-produk UMKM yang menurut penilaian kami sudah siap untuk ekspor akan kami hadirkan di stan FTA Center dalam pameran perdagangan tahunan terbesar di Indonesia yaitu Trade Expo Indonesia yang pada tahun 2018 berlokasi di Indonesia Convention Exhibition di kawasan Bumi Serpong Damai, Provinsi Banten. Bahkan pelaku usahanya berkesempatan pula untuk kami dampingi untuk bertemu dengan para calon pembeli dari luar negeri yang hadir dalam Trade Expo Indonesia tersebut. FTA Center Jakarta juga menjadi penghubung para pelaku UMKM dengan Indonesia Trade Promotion Center (ITPC) di berbagai negara yang memang mendapat tugas untuk membidik pasar ekspor (Hapsari \& Haqqi, 2015).

Sesuai dengan perkembangan teknologi komunikasi saat ini, para peserta program pemberdayaan FTA Center Jakarta difasilitasi pula untuk menjadi anggota forum diskusi melalui aplikasi WhatsApp. Forum ini selain sebagai media silaturahmi, juga dimaksudkan untuk saling berbagi informasi tentang peluang usaha serta hal-hal lain yang menunjang kegiatan pemberdayaan UMKM. Di masa pandemi Covid-19 ini, terbukti forum ini cukup efektif sebagai media komunikasi bagi sejumlah pelaku usaha yang bergerak di bidang produksi tekstil untuk memperkenalkan sekaligus memasarkan produk-produk mereka. Gambar 5 menampilkan contoh komunikasi yang dilakukan di dalam forum tersebut.

Barangkali ada temen2 yg butuh apd, model coverall

Last stock sisa produksi 240 pcs lg @80 ribu

Bahan Spunbond 75 Warna Cream
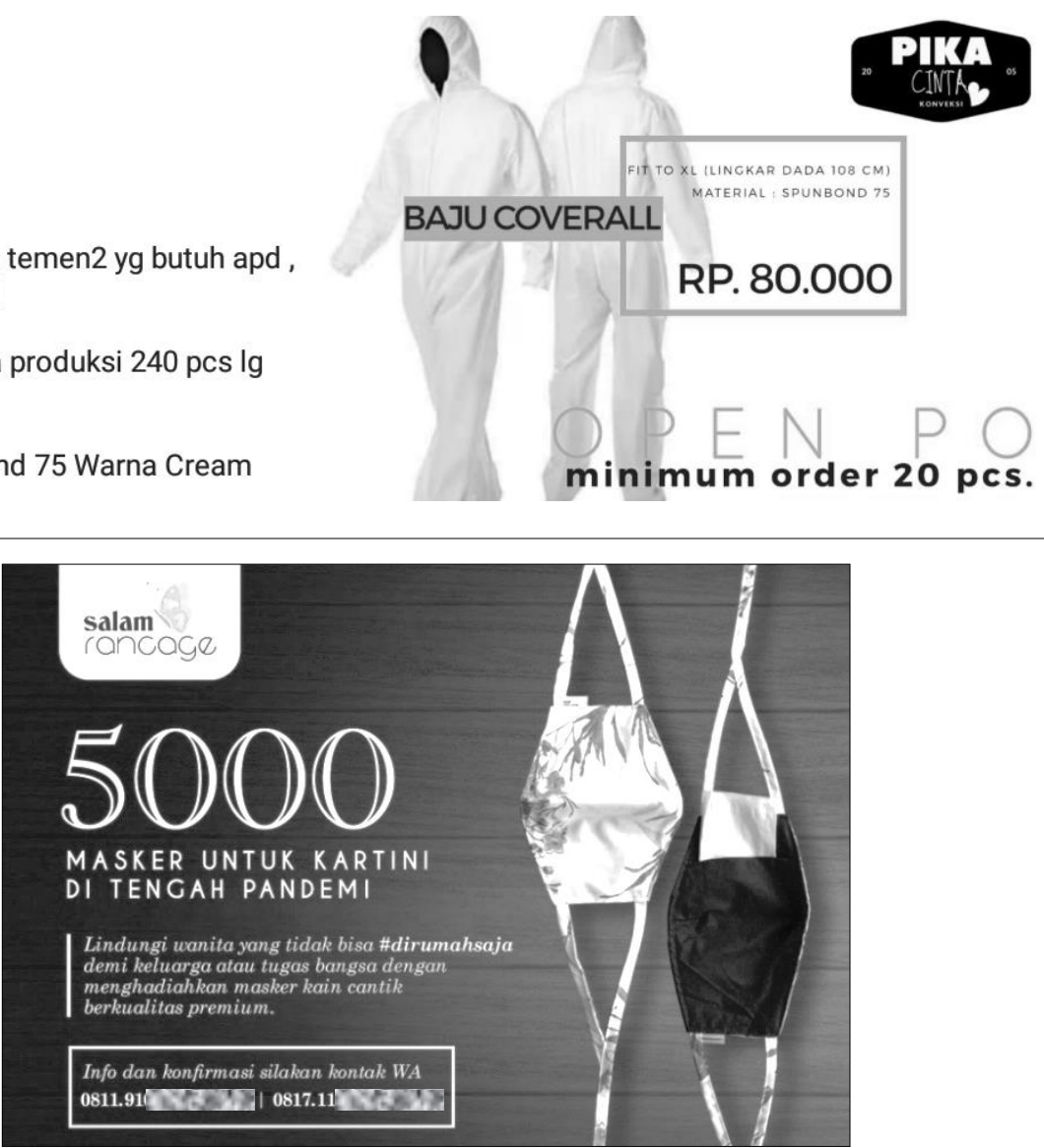

Gambar 5. Contoh promosi produk UMKM binaan FTA Center Jakarta di forum WhatsApp

\section{KESIMPULAN}

Kegiatan pemberdayaan oleh FTA Center periode 2018-2019 telah mampu melayani sekitar 100 pelaku UMKM di Jabodetabek dan juga sejumlah kawasan lainnya seperti Kalimantan 
Selatan, Jambi, Kepulauan Bangka Belitung. Secara umum telah terjadi peningkatan pengetahuan dan keterampilan para pelaku usaha dalam meningkatkan kualitas produk mereka agar mampu menjangkau pasar ekspor. Para pelaku UMKM juga berkesempatan untuk tampil dalam katalog produk yang dipromosikan oleh FTA Center Jakarta serta juga hadir dalam Trade Expo Indonesia, pameran perdagangan terbesar di negeri ini.

Kemitraan FTA Center Jakarta dengan para Pemerintah Daerah, kalangan perbankan, asosiasi pelaku usaha, universitas serta pihak-pihak lain terbukti telah mampu meningkatkan efektivitas kegiatan pemberdayaan pelaku UMKM agar mampu melakukan dan mengembangkan ekspor produk-produk mereka.

Kegiatan pemberdayaan ini harus berkesinambungan agar benar-benar dapat dicetak para eksportir handal di masa depan. FTA Center Jakarta hingga kini terus membuka pintu selebarlebarnya (termasuk melalui jalur media sosial) bagi para pelaku UMKM yang ingin memanfaatkan perjanjian perdagangan internasional yang telah dibuat Indonesia dengan mitra-mitra strategis yang jumlahnya terus bertambah.

\section{UCAPAN TERIMA KASIH}

Penulis mengucapkan terima kasih kepada rekan-rekan Tenaga Ahli di FTA Center Jakarta periode 2018-2019, yaitu Ali Akbar dan Aryoko Mochtar, serta tenaga pendukung, yaitu Izza Firdausi dan Verli Ismail, yang telah banyak membantu dalam proses penulisan artikel ini.

\section{Daftar Pustaka}

1. Aitken, M., Haggett, C., \& Rudolph, D. (2016). Practices and rationales of community engagement with wind farms: awareness raising, consultation, empowerment. Planning Theory \& Practice, 17(4), 557-576. https://doi.org/10.1080/14649357.2016.1218919

2. Hapsari, A.W., \& Haqqi, H. (2015). Peran Promosi Ekspor Indonesian Trade Promotion Centre (ITPC) Chicago dalam Perdagangan Bilateral Indonesia - Amerika Serikat Tahun 2009-2014. Transformasi, 2(28), 205-212. http://ejurnal.unisri.ac.id/index.php/Transformasi/article/view/1723

3. Hasan, M.I. (2017, May 10). FTA dan CEPA, Masih Perlukah? Berita Satu. https://www.beritasatu.com/nasional/429865-fta-dan-cepa-masih-perlukah

4. Hudlicka, E. (2013). Virtual training and coaching of health behavior: Example from mindfulness meditation training. Patient Education and Counseling, 92(2), 160-166. https://doi.org/10.1016/j.pec.2013.05.007

5. Kartiwa, A. (2020). Good Local Governance: Membangun Birokrasi Pemerintah Daerah Yang Bersih dan Akuntabel. Jurnal Wacana Kinerja: Kajian Praktis-Akademis Kinerja dan Administrasi Pelayanan Publik, 10(4), 1-16. http://jwk.bandung.lan.go.id/ojs/index.php/jwk/article/view/387

6. Kementerian Koperasi dan Usaha Kecil dan Menengah. (2018). Perkembangan Data UMKM dan Usaha Besar 2017-2018. Kementerian Koperasi dan Usaha Kecil dan Menengah Republik Indonesia.

7. Lochner, L., \& Gijselaers, W.H. (2011). Improving lecture skills: A time-efficient 10-step pedagogical consultation method for medical teachers in healthcare professions. Medical Teacher, 33 (2), 131-136. https://doi.org/10.3109/0142159X.2010.498490

8. Murtiasri, E., Suharto, \& Sartono. (2015). Peningkatan kualitas produk dan kompetensi pengrajin wayang kulit menuju pasar sasaran ekspor. Jurnal DIANMAS, 4(2), 71-82.

http://jurnaldianmas.org/index.php/Dianmas/article/view/35 
9. Riga, C. (2020). Women's Empowerment and Agency: Bottom-up and Top-down. Antrocom Journal of Anthropoloby, 16(1), 97-112.

10. Sani, A., \& HSM, M.H. (2020). Peningkatan kompetensi coach dalam program pendampingan ekspor di era disruptif teknologi. Ekonomi Bisnis, 26(1), 173-186. https://doi.org/10.33592/jeb.v26i1.617 